\title{
The Remarriage of Elite Widows in the Later Middle Ages
}

\section{Rhoda L. Friedrichs}

Among the propertied classes of the late Middle Ages, widows and widowers tended to remarry promptly and repeatedly. At one time the Church had had its doubts about the morality of second marriages, and there were certainly husbands in the fifteenth century who enjoined perpetual widowhood on their wives, ${ }^{1}$ as well as women who did not wish to remarry. There was a great deal of admiration for the widow who became a nun or lived by a quasi-monastic regimen - one thinks of Cecily of York or Margaret Beaufort. Despite these widely praised exemplars, however, the remarriage of widows was common and even expected. ${ }^{2}$ And while each country and each region had its own laws and customs, the factors that affected the ability of widows of the propertied classes to determine their own remarriages were, broadly speaking, similar across Latin Christendom. Indeed, widows of the minor aristocracy as well as those at the apex of the social pyramid encountered both possibilities and constraints which placed limitations on the power of even the freest and wealthiest women. While power and influence, whether economic or political, made a widow an attractive marriage partner, that same

1 A typical example is Sir Giles Denys, who in 1442 bequeathed all his goods to his wife Margaret on condition that she take a vow of perpetual chastity. If she remarried, she was to receive only the legally required one-third. See Swabey, Medieval Gentlewoman, 49. Provisions such as this did not always stop widows from remarrying. Like Denys, the Berkshire squire John Norris, who died in 1467, left his property to his widow Margaret on condition that she not remarry, but she became the wife of Sir John Howard six months later. See Crawford, ed., The Household Books of John Howard, xiii.

2 The well-known manual of instructions by the Menagier of Paris for his young wife repeatedly refers to her duties to her husband, "whoever he may be." A Medieval Home Companion, ed. and trans. Bayard, 55. 
power and influence drew the ambitious and the ruthless, whose strength often outweighed her own.

A bride who was a maiden brought a dowry, but a widow had a dower, conventionally one third of her late husband's property, and often a jointure as well. ${ }^{3}$ This could make a widow a highly desirable match to many prospective husbands and their families. Even a mental handicap was no deterrent: Joan Faucomberg, described as "fatua et ydeota [...] a nativitate sua," was married at fifteen to William Neville, who became Lord Faucomberg in her right. He died on 9 January 1463, and within weeks she was married again, to John Berwick. ${ }^{4}$

Young girls' marriages were made by their parents and other relatives, but widows were no longer under their fathers' direct authority and thus in many cases had a discretionary power in choosing a second or subsequent husband which had been unavailable to them at the time of their first marriage. Alternatively, wealthy widows could choose not to remarry but to live independently. ${ }^{5}$ The status of widows of the late medieval elite had such obvious advantages that it is easy to identify widowhood for these women as the freest and most advantaged part of the life cycle. ${ }^{6}$ Nonetheless, while a minority of upper-class women were able to make use of these opportunities, the limitations and constraints that typically shaped women's lives and choices appeared in the patterns of remarriage by widows of the elite, too.

While some of the early Fathers of the Church had condemned the remarriage of widows entirely, the Church ultimately accepted remarriage as permissible. ${ }^{7}$ By the thirteenth century, the ecclesiastical courts insisted that the marriages of widows, like all marriages, were made a sacrament through the voluntary consent of the spouses, and Church authorities would annul a marriage if coercion could be proved. ${ }^{8}$ While the Church

3 For a discussion of the difficulties that could surround the obtaining of dower, see Walker, "Litigation as Personal Quest," 97 \& passim. For an examination of the increasing importance of jointure, see Payling, "The Politics of Family," 29-32.

4 C[okayne], "Joan Faucomberge," The Complete Peerage, 5:285.

5 For a study of the forty-nine-year widowhood of Dame Alice de Bryene, see Swabey, Medieval Gentlewoman. For the thirty-eight-year widowhood which followed the three marriages of Elizabeth de Burgh, see Underhill, For Her Good Estate.

6 The concept of widowhood as a liberated and attractive condition also appears as a familiar theme in the literature of the late Middle Ages, including, of course, Chaucer's "Wife of Bath's Prologue" and Dunbar's "Tretis of the Twa Mariit Wemen and the Wedo."

7 Brundage, "Widows and Remarriage," 17-32. Brundage also discusses these issues more extensively in Law, Sex, and Christian Society, 68, 97, and 343.

8 Brundage, Law, Sex, and Christian Society, 439. 
insisted on freedom of choice, both feudal custom and the law imposed some restrictions on the remarriage of widows of the landed classes, although this was a matter of prohibiting certain forms of remarriage rather than requiring a second marriage. In England, the Magna Carta had forced the king to renounce the right to arrange the marriages of widows of the baronage at will, and the 1235 Statute of Merton did not allow a lord to forbid the remarriage of a vassal's widow unless she intended to marry one of the lord's enemies. However, before the end of the century, such widows could normally pay a fine to marry as they chose. ${ }^{9}$

Despite both ecclesiastical and legal rights and protections, however, in the late Middle Ages kings and feudal superiors as well as heads of families continued to play a major role in the remarriage of widows of the elite - sometimes with the assent and even the encouragement of these widows, but often by exerting pressure in a number of ways. Wealth could give a woman the power to make her own choices, but it also attracted men who hoped to acquire it, or hoped to prevent rivals from acquiring it. In many cases the power of these men outweighed that of the propertied widow. This pertains both to women of royal rank, despite the special political issues involved, and to women at all other levels of the upper classes.

\section{Royal Widows}

The most obvious category of elite widows to experience the limitations as well as the privileges of their position consisted of women of royal houses. In the political arena, women could not normally exert power directly, but they could convey power to a husband, both through their control of land and through the more intangible but equally important factor of the prestige of their blood and connections. In terms of social functioning, on the other hand, such widows had the power to advance or disparage themselves and their families through a second marriage. Perhaps the most dramatic fifteenth-century case involving demands for a speedy remarriage for the sake of power was that of Queen Elizabeth of Hungary in 1439. Elizabeth was the only child of the Emperor Sigismund, and since a woman could not succeed to the throne in Hungary, Sigismund had nominated her husband, Albert of Habsburg, as his successor. Elizabeth was pregnant at the time of Albert's death on 27 October 1439, and even before the

9 For an overview of developments in rights over the remarriage of the widows of feudal tenants, see Rigby, English Society, 263-64; and Given-Wilson, The English Nobility, 139-40 and 148. See also Rosenthal, Patriarchy and Families of Privilege, 175-256. 
birth of her son the following February, the Hungarian nobles were pressing her to marry the young king of Poland in order to provide them with the military support they needed to face the Turks. Elizabeth did not share their priorities: to her the future of her house was more important than acquiring an alliance with an unproven commander, who was in any case likely to seek to command her as well. ${ }^{10}$ She managed to avoid marriage to "the Pole," as she called him, ${ }^{11}$ by smuggling the crown of St. Stephen out of its vault and having her infant son crowned king soon after his birth. Elizabeth was able to resist the pressure of the Hungarian nobles, but only by a dangerous subterfuge, not through any intrinsic power of her position. Had her burglary adventure failed, she did not believe she could have resisted the power of the nobles to demand her remarriage, and the likely relegation of her son. ${ }^{12}$

Elizabeth of Hungary's nobles wanted a marriage to a foreign prince, but in other cases an ambitious noble would seek to marry the dowager queen himself. The experience of Joan Beaufort, queen of Scots, widowed in 1437 by the assassination of her husband James I, was typical. Soon after the king's death, she was manoeuvred out of the regency she had expected in favour of Archibald, 5th earl of Douglas. On Douglas's death two years later, she married Sir James Stewart of Lorne, apparently to gain support for a fresh attempt at the regency. If this was her plan it failed, because her remarriage sparked the hostility of all those who now saw themselves excluded from the chance to gain power. It was only a matter of weeks before Sir Alexander Livingstone won enough allies to enable him to seize and imprison both Joan and her new husband. Even after she was released, the dowager queen never regained either political power or the custody of her son. ${ }^{13}$

Both Elizabeth of Hungary and Joan Beaufort, queen of Scots, were regents for a child king; their unusual degree of power naturally led ambitious men to try to access it for themselves. Thus, these exceptionally powerful widows were for that very reason

10 Elizabeth seems to have resisted Albert's attempts to exact obedience from her. She ignored insistent messages from him summoning her to his sickbed. See Williamson, trans., The Memoirs of Helene Kottanner, 23.

11 Williamson, trans., The Memoirs of Helene Kottanner, 3. Wladislaw of Poland was sixteen at the time. Elizabeth was thirty-one.

12 In 1192, when the nobles of the Crusader kingdom succeeded in requiring Queen Isabella to remarry one week after the assassination of her husband, they considered the possibility that she might be pregnant by her late husband unimportant compared to the need for a military leader. See Runciman, A History of the Crusades, 3:66.

13 See Brown, James I, 180 and 199; and McGladdery, James II, 17. 
exceptionally vulnerable to pressure and even coercion to remarry to suit the political needs of others. Yet even royal widows who did not wield political power also found that their remarriage was a political issue, and often an unresolvable one. In remarrying, a widowed queen normally had two options: either to marry a member of the nobility, or to marry considerably beneath her. ${ }^{14}$ Both situations were problematic. If she married a noble, she would advance him far beyond others of his rank, which his rivals would resist. But marrying a man of lower station presented a different complex of problems. First, of course, it disparaged the royal house, and thus the aristocracy as well. But it also vitiated the potential power the queen dowager represented: only a noble, and one of the higher nobility at that, had the personal stature to wield that power. Katherine of Valois is the most famous example in England of the conundrum with which a royal widow was faced. The Council intervened to prevent her marriage to a noble by requiring royal permission for the remarriage of a king's widow, permission which was never granted. ${ }^{15}$ When Queen Katherine's eventual secret marriage to Owen Tudor became public, the result was not only punishment but disgrace: a lady who married beneath her station was clearly heeding not love, which required dignity and equality of status, but sheer lust. The same opprobrium attached to other widows with connections to the royal house, and to widows of the nobility in general. In 1297, for example, Edward I's daughter Joan, the widow of the earl of Gloucester, married an esquire of her household - a man of a rank similar to Owen Tudor's. The king was enraged - he had been negotiating a marriage for her with the count of Savoy — but eventually he restored her to favour and even allowed her new husband to use the titles of his predecessor. ${ }^{16} \mathrm{~A}$ generation later, however, Joan's children were still the butt of scurrilous jokes: their mother had been a woman governed by lust. ${ }^{17}$ The same attitudes could be found in the fifteenth century: Richard Wydeville, the second husband of John duke of Bedford's widow Jacquetta of Luxembourg, was sneered at as a man without nobility of blood who was promoted far beyond his proper place by mere royal favour. ${ }^{18}$

14 An exception was Anne of Brittany, whose marriage contract with Charles VIII of France specified that in case of his death without heirs she should marry his successor, as indeed transpired.

15 It has been suggested that the Council was aware of the clandestine marriage and used the statute to force Queen Katherine to avoid the public eye. Certainly, she had spent the 1420s at court, but after 1430 she resided principally on her estates. For a discussion of this issue, see Griffiths, "Queen Katherine of Valois."

16 C[okayne], The Complete Peerage, 5:710.

17 Haines, Edward II, 74 and 389-90 n. 70.

18 Paston Letters and Papers, ed. Davis, 1:162. 
This is not to say that a royal widow could not remarry successfully — but such a marriage was expected to be arranged not by the widow alone, but through the agency and in the interests of her family. Isabella of Valois, the child widow of Richard II, was returned to her father, Charles VI of France, who arranged a second marriage for her with the duke of Orleans. Another Isabella, the daughter of Ferdinand of Aragon and Isabella of Castile, was left a young widow by the death of her husband, the Portuguese crown prince. Although she wished to become a nun or at least to remain unmarried, she at last acceded to her parents' plans for her to marry the new Portuguese king, Manuel I. ${ }^{19}$

A far more mutually satisfying arrangement was made for Joan of Navarre, the widow of the duke of Brittany, when she married Henry IV of England in a second marriage. Henry's choice of Joan as his second wife has generally been considered a rather unimpressive match, probably the best available to a usurper still facing challenges to his throne. ${ }^{20}$ Henry had met Joan during his exile in 1399, while the then duke of Brittany was still alive, and it has been suggested that she had taken his fancy at that time - in other words, that he had married her for reasons of the heart. Certainly she brought him neither wealth nor power, and in fact she had to give up both in order to make this marriage: following her proxy wedding to King Henry in April 1402 she was required to renounce not only the regency of Brittany but also the guardianship of her three sons, although her two unmarried daughters were allowed to accompany her to England; in addition, she had to surrender her dower in exchange for a personal allowance. ${ }^{21}$ Perhaps Henry had indeed formed an attachment to Joan - but Joan was not available when he met her, and he had considered marriage with several other ladies on his travels. ${ }^{22}$ It was only in late 1401 that Joan's agents were sent to England "to conduct certain business" with the king. ${ }^{23}$ The negotiations were ostensibly with the widowed duchess on her own behalf, but by the time she applied for a papal dispensation to marry whomever she chose within the fourth degree, the marriage had been approved by the king of France and the leading French princes of the blood, including the duke of Burgundy. It seems that this is where the value of this marriage lay for King Henry. At the same time, Joan's second marriage was made to promote the interests of her family, just as her first had been.

19 Rubin, Isabella of Castile, 361-62.

20 In late 1400, the French royal envoys were still referring to Henry as "he who calls himself King of England"; see Wylie, History of England under Henry the Fourth, 1:150.

21 Wylie, History of England under Henry the Fourth, 1:308.

22 He had entered negotiations for a daughter of the Duke of Berry and had considered a daughter of the Duke of Milan. Wylie, History of England under Henry the Fourth, 1:85 and 4:128.

23 Wylie, History of England under Henry the Fourth, 1:261. 


\section{Noble Widows}

Politics did not play the same role for widows of the aristocracy and gentry, but their control of wealth and land, and the potential for regional consequence which this represented, made comparable inroads on these widows' freedom to arrange their own remarriages. A widow, like everyone else, was not an isolated individual but part of a web of familial relationships. The family would regard her remarriage in light of its impact on the position of the family as a whole and thus would feel entitled to involve itself. In some cases, widows apparently shared that view and welcomed the assistance of their kindred. ${ }^{24}$

While the suitors of young girls would approach their fathers or other relatives and only encounter the possible bride when negotiations were well under way, ${ }^{25}$ widows were central to the making of their own later marriages. When, for example, in 1472 William Stonor sought to marry Margery Blount, the widow of Lord Mountjoy's heir, it was Margery herself whom he approached, plying her with "love's lore" while his friends and family pondered the financial possibilities. Ultimately, it was Margery who decided not to accept William. ${ }^{26}$

On the whole, society expected successful marriages at every level and regardless of the age of the spouses to be the outcome of the prudent deliberation of the older and wiser members of the family. Nuptes carnales in luctu terminant, ran the proverb: carnal marriages end in strife. Even widows, if they ignored their family's advice, might well follow their hearts to destruction. Few would have been surprised at the sad experience of Jeanne de Sauveuse, who, in 1525, was left a widow with substantial property in northern France. Although her extended family proposed two suitable and wealthy gentlemen, Jeanne allowed herself to be persuaded to marry Thibaud de Riou, the charming and impecunious brother of a friend. The man of her choice turned out to be a pathological gambler, who wasted away her children's inheritance and even broke open her locked coffers to seize her family heirlooms to pay his debts. ${ }^{27}$ Her family washed their hands of the matter.

24 The most striking such case is the secret marriage of Elizabeth Wydeville to Edward IV. As the impoverished widow of Sir John Grey, she was living with her mother, the dowager duchess of Bedford, who hosted the king's clandestine visits and promoted the marriage. See Okerlund, Elizabeth Wydeville, 29.

25 John Paston, for example, first met Margaret Mautby, his bride-to-be, when she was brought to the Paston home shortly before their marriage. His mother thought they got on well, and hoped "per shal nede no gret trete be-twyxe hym"; Paston Letters and Papers, ed. Davis, 1:26.

26 Kingsford's Stonor Letters and Papers, ed. Carpenter, 123-28 [211-16], letters 121-24, esp. 121.

27 The Lisle Letters, ed. Byrne, 121-24. 
Jeanne de Sauveuse was not dependent on a powerful and high-ranking relative, or her story might well have been more like that of Margaret Lucy. Margaret was left a childless widow in her twenties when her husband, Sir William Lucy, was killed at the Battle of Northampton in 1460. Her jointure was declared void since it had been made without royal license, and there was a delay of almost two years in assigning her dower, leaving her in straitened circumstances. ${ }^{28}$ Her mother had been a cousin of the earl of Warwick, and this powerful kinsman apparently took Margaret into his household. Despite her lack of riches, some two years after her husband's death she was being courted by Thomas Danvers, a rising lawyer, who said "that he loved the said Margaret as was possible for any earthly man to love a woman." ${ }^{29}$ Although both of them were aware that the earl would not approve of the match, they exchanged vows verba de presenti, that is, binding vows of marriage, with her brother Sir Henry Lewis providing a

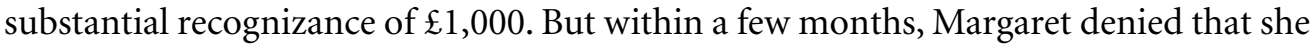
had made binding vows and married one of Warwick's retainers, Thomas Wake. Danvers petitioned the bishop of Lincoln for annulment of this second marriage and confirmation of his marriage to Margaret. The bishop handed the case over to the archbishop of York, who was the earl of Warwick's brother. The case went on to the royal chancery, then to Rome, and finally back to a panel of three English bishops, and was still unresolved when Margaret died, as the wife of Thomas Wake, in 1466. ${ }^{30}$ Margaret Lucy had hoped to make a love match by presenting the earl with a fait accompli, but the earl took advantage not only of the power of his position and her own obligation to him, but also of the deference of the Church and the courts. Margaret could not resist his plans to use her as one more element in building his network of supporters.

Margaret Lucy was not wealthy or independent enough to be able to carry off her love match, but other, better placed widows were able to make a choice based on personal attraction, though often at a high price. ${ }^{31}$ Since the thirteenth century, widows of tenants-in-chief had been entitled to pay the Crown for license to remarry. The fee of two hundred marks which Elizabeth, widow of Sir John Clifford, paid in 1426 was not atypical. ${ }^{32}$ In fact, these payments, and even penalties for remarrying without a license, could sometimes be remitted: in 1401, for example, Elizabeth FitzAlan, widow of Thomas

28 Hicks, Edward V, 35.

29 Hicks, Edward $V, 36$.

30 Hicks, Edward $V, 36$.

31 As McSheffrey notes, "by no means was it unusual for landed widows" to marry down the social scale; McSheffrey, Marriage, Sex, and Civic Culture, 102.

32 Griffiths, The Reign of King Henry VI, 87. 
Mowbray, duke of Norfolk, married Robert Goushill without royal license. Her dower lands were initially seized by the Crown but restored after a month. ${ }^{33}$ A generation later, in 1424, Alice Sergeaux, dowager countess of Oxford, also had her dower lands seized and then restored following her unlicensed remarriage to Nicholas Thorley, but a fine of $\mathfrak{E} 100$ and one year's income from her estates was still imposed. ${ }^{34}$ Fines for remarriage without royal license were a source of income for the Crown, and during the minority of Henry VI enormous penalties could be demanded. In 1423 Margery

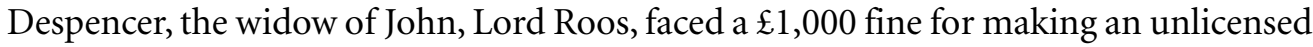
marriage to the esquire Roger Wentworth, while the remarriage of Anne Stafford, the widowed countess of March, to John Holland, earl of Huntingdon, cost the couple a fine of 1,200 marks. ${ }^{35}$ Fines for unlicensed remarriage could also be opportunities for outright plunder by the powerful. Jacquetta of Luxembourg, the young widow of John, duke of Bedford, married the esquire Richard Wydeville without license in 1436, although she had been granted dower on the condition that she not remarry without license. ${ }^{36}$ As a result, she and her new husband suffered "right grate streitnesse" and petitioned the king to set a reasonable fine. ${ }^{37}$ The fine was set at $\mathfrak{E} 1,000$, a considerable sum given that her dower was valued at over $\mathfrak{£} 4,000$ p.a. — but that was only the legal penalty. ${ }^{38}$ Jacquetta was also forced to make over lands worth a staggering 13,350 marks to Cardinal Beaufort, permanently reducing the income from her dower. ${ }^{39}$

Many widows of the elite married men who were of lower standing than their late husbands or their fathers had been. The marriage of aristocratic widows into the gentry was common enough for lesser men like William Stonor to have hopes of marrying Margery Blount, the widow of Lord Mountjoy's heir, as mentioned above, and for John Paston (III) to pursue Elizabeth Tilney, the widow of the duke of York's nephew Humphrey Bourchier, although neither of these marriages was realized..$^{40}$ Nonetheless, if an aristocratic widow married a man too far down the social scale to wield effectively the power she and her property represented, the result could be contempt and opprobrium. The earl of Warwick taunted the distinguished soldier Richard Wydeville, by

33 Calendar of Close Rolls (hereafter, CCR) 1399-1402, 134 and 381.

34 Griffiths, The Reign of King Henry VI, 87.

35 Griffiths, The Reign of King Henry VI, 87.

36 Baldwin, Elizabeth Woodville, 2.

37 Baldwin, Elizabeth Woodville, 2.

38 Baldwin, Elizabeth Woodville, 2 and 5.

39 Okerlund, Elizabeth Wydeville, 40.

40 Paston Letters and Papers, ed. Davis, 1:441. 
then Lord Rivers, as the son of a mere squire advanced beyond his deserts by his marriage to the duchess of Bedford. ${ }^{41}$ Contempt for the low-born man attempting to fill shoes too large for him was not limited to the aristocracy. In the 1470s, the widowed Jane, Lady Cromwell married Robert Radcliffe, who had been an escheator, a sheriff, and an estate agent for the earl of Warwick. His wife's feoffees, men with careers similar to his own, regarded him as ridiculously inadequate to the task of maintaining her estates, and worked successfully to block his efforts at managing her estates and income. ${ }^{42}$

The marriage of an aristocratic widow to a man of lower station is often taken to be a love match, by a woman free at last to choose for herself. But these widows might also marry men of lower status for reasons other than romantic ones. The collapse of the Lancastrian cause and the defeat of its leaders imposed a different kind of constraint on at least one of their widows. Eleanor Beauchamp, duchess of Somerset, widow of the greatest enemy of the Yorkists, had her property seized in 1463 when her son, too, took up arms against Edward IV. The duchess was sheltered by her former sister-in-law Lady Welles, and within a few months married Walter Rokesley, a gentleman employed in that household. A pardon for the duchess followed her remarriage, with the restoration of her Somerset dower: evidently a great lady who had disparaged herself in this way was no longer a credible focus for dissidents, and her new husband did not have the standing to make political use of Somerset's lands. ${ }^{43}$ The daughter of the earl of Warwick and twice the widow of a peer - her first husband had been Thomas, Lord Roos the duchess had chosen, or been driven to, a humble remarriage as a shelter: by marrying down she had protected herself from political retribution.

Other widows of a king's fallen enemies could face a different kind of limitation of their liberty to choose. Edward IV notoriously arranged the marriage of John Wydeville, the twenty-year-old brother of his queen, to the thrice-widowed Katherine, duchess of Norfolk, who was sixty-six. The Duchess Katherine had successfully negotiated her own remarriages twice before and had done so in a manner that would keep control of her extensive Norfolk dower lands for herself. The situation was different in the case of this maritagium diabolicum - in William Worcester's caustic phrase — not because the

41 Paston Letters and Papers, ed. Davis, 1:162.

42 Oxford, Magdalen College, Misc. MSS 361.

43 Jones and Underwood, The King's Mother, Lady Margaret Beaufort, 31 and 33. Lady Jane Grey's mother, Frances, dowager duchess of Suffolk, was to do the same a century later. Following the executions of her husband and daughter for treason, the duchess married a gentleman of her household. Queen Mary did not take any action against her, although her claim to the throne was even stronger than her daughter's had been. 
duchess was less astute but because her third husband, John, viscount Beaumont, had fallen in battle on the Lancastrian side. Her penalty was to make her extensive properties useful to a protegé of the king's. ${ }^{4}$

\section{A Case Study - Maud Stanhope, Lady Willoughby}

For many of these cases of remarriage, the evidence is largely indirect, but the surviving documentation concerning the lives of some aristocratic women, particularly heiresses, makes it possible to take a more detailed look at the ways in which widows remarried. The marital career of one woman, Maud, Lady Willoughby, can be seen to demonstrate the range of possibilities and limitations on the remarriage of widows in the upper strata of society. Maud Stanhope was born into the gentry, probably in $1424 . .^{45}$ Her father, Sir Richard Stanhope, held lands and offices in Nottinghamshire, but her mother had been born into the peerage, the daughter of Lord Cromwell of Tattershall. Maud's father had died in 1436, and it was her uncle, Ralph, Lord Cromwell, who arranged her first marriage, to Robert, Lord Willoughby. This marriage, like most first marriages of young women from noble families, was made to suit the interests of the parental generation - Lord Willoughby owed money to his neighbour, Lord Cromwell, and he seems to have agreed to accept the cancellation of his debt as part or all of the dowry. ${ }^{46}$ The marriage took place sometime before 1448, when Maud was in her early twenties; Lord Willoughby was a widower with a daughter of the same age as his bride. ${ }^{47}$ The disparity in age does not appear to have troubled Lady Willoughby, who seems to have agreed with her uncle that marriage to a peer was a very advantageous settlement, as his executors were to remind her during a dispute over her inheritance some years later. ${ }^{48}$ When Lord Willoughby died in 1452, however, all advantage rested with her stepdaughter. Joan Willoughby and her husband Sir Richard Welles seized the estate, including the lands specified as Maud's dower, and drove out her father's widow. The

44 The duke of Norfolk, her son by her first marriage, had supported Edward IV, but her daughter by Lord Beaumont received only four manors of all the estates seized by the Crown after her father's death at the Battle of Northampton. Stapleton, ed., De Antiquis Legibus Liber, ccxii-ccxiii.

45 Her age is given as thirty in her mother's inquisition post mortem in December 1454 (PRO, Inquisitions Post Mortem C/139/157/26). For an examination of the fate of Lady Willoughby's inheritance, see Friedrichs, "Rich Old Ladies Made Poor," passim.

46 Oxford, Magdalen College, MSS 431 and 127/34.

47 Joan Willoughby was twenty-seven at her father's death in 1452, putting her birth in 1425; C[okayne], The Complete Peerage, 12/2:666.

48 Oxford, Magd. MS Misc. 362. 
new Lady Willoughby apparently commanded more loyalty from her servants than did the dowager, for none of the estate agents seem to have spoken up for the widow's rights. ${ }^{49}$ Maud sent a desperate message to her uncle asking him to send an escort "to help and convey her unto Tatteshale so that she myght be ther for hir most comford suerte and worship as the cas than required." 50

Lady Willoughby was thus left without the financial independence that gave a widow scope for choice of a second husband, and without the social independence as well: with no dower house of her own, she remained dependent on her uncle and resident in his household. Her one asset was his wealth and prominence, and that was his to use, as it had been when he married her to Lord Willoughby. Ten months after Lord Willoughby's death, Cromwell arranged a second marriage for his widowed niece, this time to gain allies against his political enemies. In August of 1453, Maud was married to Thomas Neville, the second son of the earl of Salisbury. ${ }^{51}$ This marriage lasted seven years, until Neville was killed at the Battle of Wakefield.

It was only after this second widowhood, with her powerful uncle dead as well, that Lady Willoughby, as she still called herself, was able to make her own marriage. It flew in the face of all prudence and common sense, and was in all probability a love match. Maud Stanhope would have known Sir Gervase Clifton when she was a young girl at court and he was the duke of Gloucester's treasurer. Clifton went on to a distinguished career in the French wars and in parliament, and by 1461 he was a widower, probably in his fifties. ${ }^{52} \mathrm{He}$ and Lady Willoughby were married within months of Thomas Neville's death. Clifton was not only of lower standing than either of her previous husbands, but he was of illegitimate birth; his properties were in Kent, far from her own estates in East Anglia and the Midlands. Worse still, he was committed to the Lancastrian cause: he was not on the list of those pardoned when Edward IV came to the throne. ${ }^{53} \mathrm{~A}$ pardon was finally granted in 1465, but only after he and his wife made over the bulk of her Cromwell inheritance - lands worth 400 marks a year — to the king's brother-in-law Antony Wydeville. ${ }^{54}$ Clifton was still loyal to the House of Lancaster, and he was one of

49 Two years later Maud still had not received her dower or any equivalent properties. Calendar of Patent Rolls (hereafter, CPR) 1452-1461, p. 51.

50 Oxford, Magd. MS Misc. 431.

51 A marriage license was issued in May 1453; the wedding took place three months later. CPR 1452-1461, p. 64 .

52 CPR 1452-1461, pp. 171, 214, 467.

53 CCR 1461-1468, p. 55.

54 CCR 1461-1468, p. 330; Oxford, Magd. MS Misc. 261/14. 
those executed after the Battle of Tewkesbury in 1471, leaving Lady Willoughby a widow for the third time. She was so impoverished that a year later she had to borrow money from a London merchant in order to afford to pay for Christmas festivities for her household. ${ }^{55}$ At age forty-seven, and with little property and no further powerful connections, Lady Willoughby was in no position to choose another husband; perhaps her misfortunes made her unwilling to embark on a fourth marriage. In any case, she remained a widow for the last twenty-six years of her life.

Widowhood has been regarded as a uniquely advantageous state for women of property in the late Middle Ages. It was a commonplace in the fourteenth and fifteenth centuries that women longed to be widows because of the freedom of action and of choice which widowhood brought them. ${ }^{56}$ But despite the provisions of canon law and feudal custom, even at the best of times this freedom was contingent on a complex of factors: age, personality, social constraints and, of course, wealth. In times of crisis, political need could quickly supersede all of a widow's rights and perquisites. The wealthier and more highly placed a widow was, the more power she potentially could convey - but it was precisely these widows who were most subject to the needs and intervention of powerful men and families.

The ability of widows of the upper classes to arrange their own second and subsequent marriages is often regarded as one instance of women's power despite the restrictions imposed by a masculine society. But that power was in fact sharply limited, particularly for the most highly placed. When kings or noblemen saw the remarriage of a widow as a means to advance their own interests, the widow could generally be pressured or coerced into complying. Elite widows continued to have space to manoeuvre, but in practice any freedom of choice existed on sufferance only, whatever its status in law or custom.

\section{Douglas College, New Westminster}

55 Oxford, Magd. MS Misc. 261/12.

56 Christine de Pisan, who had to struggle with serious financial and legal difficulties as a widow with young children, nonetheless said, "if in married life everything were all repose and peace, truly it would be sensible for a woman to enter it again, but because one sees quite the contrary, any woman ought to be wary of remarriage. [...] for those who are well enough off [...] it is sheer folly"; The Treasure of the City of Ladies, 159. 


\section{Bibliography}

Baldwin, David. Elizabeth Woodville: Mother of the Princes in the Tower. Stroud, Glos.: Sutton, 2002. Bayard, Tania, ed. and trans. A Medieval Home Companion: Housekeeping in the Fourteenth Century. New York: HarperCollins, 1991.

Brown, Michael. James I. Edinburgh: Canongate Academic, 1994.

Brundage, James A. Law, Sex, and Christian Society in Medieval Europe. Chicago: Univ. of Chicago Press, 1987.

— . "Widows and Remarriage: Moral Conflicts and Their Resolution in Classical Canon Law." In Wife and Widow in Medieval England, edited by Sue Sheridan Walker, 17-32. Ann Arbor: Univ. of Michigan Press, 1993.

Calendar of the Close Rolls Preserved in the Public Record Office: Henry IV, Vol. 1, 1399-1402. London: H.M.S.O., 1927.

Calendar of the Close Rolls Preserved in the Public Record Office: Edward IV, Vol. 9.1: 1461-1468. London: H.M.S.O., 1949.

Calendar of the Patent Rolls Preserved in the Public Record Office: Henry VI, Vol. 6, 1452-1461. London: H.M.S.O., 1910.

Christine de Pisan. The Treasure of the City of Ladies. Trans. Sarah Lawson. Harmondsworth: Penguin, 1985.

C[okayne], G. E. The Complete Peerage. Ed. Vicary Gibbs and H. A. Doubleday. Rev. ed. 13 vols. London: St. Catherine Press, 1910-1959.

Crawford, Anne, ed. The Household Books of John Howard, Duke of Norfolk: 1462-1471, 14811483. Stroud, Glos.: Sutton, 1992.

Friedrichs, Rhoda L. "Rich Old Ladies Made Poor: The Vulnerability of Women's Property in Late Medieval England." Medieval Prosopography 21 (2000): 211-29.

Given-Wilson, Chris. The English Nobility in the Late Middle Ages: The Fourteenth Century Political Community. 2nd ed. London and New York: Routledge \& Kegan Paul, 1996.

Griffiths, Ralph A. "Queen Katherine of Valois and a Missing Statute of the Realm." Law Quarterly Review 93 (1977): 248-58.

- The Reign of King Henry VI: The Exercise of Royal Authority, 1422-1461. Berkeley: Univ. of California Press, 1981.

Haines, Roy Martin. Edward II: Edward of Caernarfon - His Life, His Reign, and Its Aftermath, 12841330. Montreal and Kingston: McGill-Queen's Univ. Press, 2003.

Hicks, Michael A. Edward V: The Prince in the Tower. Stroud, Glos.: Tempus, 2003.

Jones, Michael K., and Malcolm G. Underwood. The King's Mother: Lady Margaret Beaufort, Countess of Richmond and Derby. Cambridge: Cambridge Univ. Press, 1992.

Kingsford's Stonor Letters and Papers, 1290-1483. Ed. Christine Carpenter. Camden Classic Reprints No. 1. Cambridge: Cambridge Univ. Press, 1996.

The Lisle Letters: An Abridgement. Ed. Muriel St. Clare Byrne. Selected and arranged by Bridget Boland. Chicago: Univ. of Chicago Press, 1982.

McGladdery, Christine. James II. Edinburgh: John Donald, 1990. 
McSheffrey, Shannon. Marriage, Sex, and Civic Culture in Late Medieval London. Philadelphia: Univ. of Pennsylvania Press, 2006.

Okerlund, Arlene. Elizabeth Wydeville: The Slandered Queen. Stroud, Glos.: Tempus, 2005. Oxford, Magdalen College Misc. MSS 127/34; 261/12; 261/14; 361; 362; 431.

Paston Letters and Papers of the Fifteenth Century. 2 vols. Ed. Norman Davis. Oxford: Clarendon Press, 1971.

Payling, Simon. “The Politics of Family: Late Medieval Marriage Contracts.” In The McFarlane Legacy: Studies in Late Medieval Politics and Society, edited by R. H. Britnell and A. J. Pollard, 21-47. Stroud, Glos.: Alan Sutton; New York: St. Martin's Press, 1995.

Public Record Office, London: Chancery, Inquisitions Post Mortem, C/139/157/26.

Rigby, S. H. English Society in the Later Middle Ages: Class, Status and Gender. New York: St. Martin's Press; Basingstoke: Macmillan, 1995.

Rosenthal, Joel T. Patriarchy and Families of Privilege in Fifteenth-Century England. Philadelphia: Univ. of Pennsylvania Press, 1991.

Rubin, Nancy. Isabella of Castile: The First Renaissance Queen. New York: St. Martin's Press, 1991. Runciman, Steven. A History of the Crusades. Vol. 3, The Kingdom of Acre and the Later Crusades. New York: Harper and Row, 1954.

Stapleton, Thomas, ed. De Antiquis Legibus Liber: Cronica Maiorum et Vicecomitum Londoniarum .... London: Camden Society, 1846. Reprint, New York and London: AMS Reprints, 1968.

Swabey, Ffiona. Medieval Gentlewoman: Life in a Gentry Household in the Later Middle Ages. New York: Routledge, 1999.

Underhill, Frances A. For Her Good Estate: The Life of Elizabeth de Burgh. New York: St. Martin's Press, 1999.

Walker, Sue Sheridan. "Litigation as Personal Quest: Suing for Dower in the Royal Courts, circa 1272-1350." In Wife and Widow in Medieval England, edited by Sue Sheridan Walker, 81108. Ann Arbor, Mich.: Univ. of Michigan Press, 1993.

Williamson, Maya Bijvoet, trans. The Memoirs of Helene Kottanner (1439-1440). Cambridge: D. S. Brewer, 1998.

Wylie, James Hamilton. History of England under Henry the Fourth. 4 vols. London: Longmans, Green, 1884-1898. Reprint, New York: AMS Reprints, 1969. 
